\title{
Subjects of Truth: Resisting Governmentality in Foucault's 1980s
}

\begin{abstract}
Responding to ongoing concerns that Michel Foucault's influential governmentality analytics fail to enable the study of "resistance", this paper analyses his last two lecture courses on "parrhesia" (risky and courageous speech). While Foucault resisted resistance as an analytical category, he increasingly pointed us towards militant, alternative, and insolent forms of counter-conduct. The paper comparatively analyses Foucault's reading of Plato, Socrates and the Cynics, exploring parrhesia's episteme (its truth-knowledge relations), techne (its practice and geographies), identities (its souls and its bodies) and its possible relations to the present. It concludes that Foucault viewed resistance as power, which problematized governmentalities but could also be analysed as a governmentality itself.. In pursuing parrhesia Foucault reaffirmed his commitment to studying discourse as always emplaced and enacted, whilst sketching out the geographies (from the royal court and the democratic Assembly to the public square and the street) that staged the risk of truth-talking. This suggests new subjects and spaces to open up political possibilities when exploring the geographies of governmentalities.
\end{abstract}

\section{Resistance is futile? Parrhesia as Governmentality}

Perhaps the most enduring critique of the work of Michel Foucault is that he paid insufficient attention to subjects and spaces of 'resistance'. To many he is the "scribe of power" (Said, et al., 1993 [2004], 214), drawing our attention to ordered Enlightenment discourses of historical knowledge, all-seeing panoptic forms of architecture, and the places in which subjects are made to care for themselves in line with broader governmentalities which work to stabilise and secure populations, economies and societies. This is in spite of the recurrence of seemingly resistant subjects and spaces throughout his work: the science-refusing insane, rebelling within the asylum; the criminal who resisted the panopticism of a disciplinary society; the sadist, the masochist, and the homosexual who refused what would later be termed 'heteronormativity' in spaces of sexual experimentation; and the much discussed insistence that power is everywhere accompanied by resistance (Foucault, 1979, 95; Foucault and Sassine 1979 [2016] 43; 1982 [2001], 346). The reason the latter are not taken to mark out Foucault as a theorist of resistance is that these subjects and spaces are often studied in the process of being normalised; as externalities which serve only to strengthen and refigure apparatuses of power (psychiatry, the criminal justice system, sexology and the bourgeois family, and theories of power themselves) in the moment of internalisation. Resistance, that is, becomes merely a 
problematisation, a source for fine-tuning power and devising yet more ingenious imbrications of sovereign, disciplinary and bio-power into new governmentalities. This stands against standard definitions of resistance within geography, which identify it as the resisting of domination or oppression, building on well-established political movements (for instance Marxist, feminist or anticolonial) as inflected by the cultural turn, the study of 'weapons of the weak' and an emphasis on political identities (Routledge, 2009, 647, where Foucault is cited as encouraging the study of resistance as hegemony).

To reduce Foucault's engagements with 'resistance' to marginal subjects and abstract theorisations is, however, to caricature his long engagement with the question of power and its effects. His work on disciplinary forms of power retained a commitment to considering "plebeian" resistance to normalisation (Ransom, 1997) while he continued to consider rights as a basis from which to resist power relations of domination (Golder and Fitzpatrick, 2008). When he up-scaled from micro to macro interventions, from individual bodies into the population, he alerted us to forms of counter-conduct and alternative pastoral traditions (Foucault, 1977-78 [2007]). What the latter drew him towards were forms of self-making that refused societal norms and their attempts to fashion the individual. While he would retain his earlier interests in knowledge formations (refashioned as veridiction) and power relations (refashioned as governmentality), the last five years of his life saw Foucault focus on the making of the self (ethics) in relation to the making of others (politics). He suggested that the medium and object of self-other relations was 'truth': asking people what their truth was; ascribing them to regimes of truth; and encouraging practices which would embed them within bodies of truth. Making them, we could say, subject to truth (Legg, 2016).

\section{Foucault's 1980s}

The majority of Foucault's 1980s publications and recently published lecture courses yoked truth to power. They bring us to Greco-Roman inward-facing regulations of (male) sexual relations with bodies, wives and boys (Foucault, 1986b), considered through lenses of dietics, economics or erotics (Foucault, 1986a) as 'care of self', or to early Christian forms of baptism, penance and spiritual direction as genealogies of confession (Foucault, 1979-80 [2014]). This material is dazzlingly rich and shows how self-fashioning (the self on self), rather than more abstract notions of subjectification, helps us understand the capillary circulation of normalising power (see McGushin, 2007 and Raffnsøe, et al., 2016, chapter 10). But for those seeking evidence of the ever-presence of resistance to and within power, this material offers precious little to work with.

Until, that is, one turns to Foucault's last two lecture courses. In English they appeared as The Government of Self and Others (Foucault, 1982-83 [2010], henceforth referenced as GSO) and The 
Courage of Truth (the Government of Self and Others II) (Foucault, 1983-84 [2011], henceforth referenced as $C T$ ). In them we see the truth-relations of self-making being studied not as inward-facing but as outward-glaring. Here self-other relations do not position the self as master/coloniser and the other as slave/colonised, rather the self under study is the intransigent subject, putting themselves at risk so as to, one might say, 'speak truth to power'. The subject of both lecture courses is parrhesia in European antiquity, a "spidery" (GSO, 45) notion on the edges of western civilisation but one which involves a speaker exposing themselves to risk (from shame and demotion to ostracism, exile or death) in order to intervene in a particular period and place (CT, 9, also see Foucault and Burchell 2015).

Here, at last, we have the resistant subject! God-shaming, empire-shaking, tyrant-challenging, and politics-claiming. That is, at least, until one reads the lectures. What we find there are parrhesiastic subjects that use their truth-talk: to found Athens; to be brave enough to govern well through the Athenian Assembly; to fearlessly advise tyrants on how better to sustain their empires; to refuse political service in favour of personal tuition; and, finally, we find the Cynic who choses militant and radical resistance to the satisfied norms of the people of the polis, but only so that he might save them.

Does, therefore, parrhesia constitute 'resistance'? In what follows I would like to suggest that Foucault refuses any easy elision of parrhesia and resistance; the latter term is almost entirely absent from the lectures (although see GSO 216, 286 and CT 258, 261, 300). Rather, what we see is that all forms of 'resistance' are forms of power relation and, crucially, that this does not disqualify them from being politically transformative, radical or dangerous. Just as Foucault insisted that disciplinary power was 'productive' rather than being 'negative', so what we might call resistance should also be viewed as 'productive' rather than romantically and uniformly 'positive'. What it produces are new reflections on how people relate to themselves, to others, and to their environments; making them, we could say, subjects of truth.

After introducing literature addressing Foucault and resistance from within and beyond the geographical discipline, this paper will perform an analytical reading across the 1982-83 lectures (referred to as Self and Others) and the 1983-84 course (referred to as Courage of Truth). Rather than focusing on what Foucault termed political parrhesia, being the courage to ascend above the masses and govern well, it will focus on what Foucault termed philosophical parrhesia, which though less obviously political takes us closer to acts of ethical self-formation and what we could call resistance. The reading deploys analytical categories developed in governmentality studies (see Legg, 2016) to read across three foci of philosophical parrhesia (Plato, Socrates and the Cynics). Although Foucault refers more to government than governmentality in these lectures, he is explicit that this is a 
continuation of his history of governmentality project (GSO, 42), connecting together the techniques of governmentality to modes of veridiction and practices of the self $(\mathrm{CT}, 8)$. The comparative reading below explores parrhesia's episteme (its truth-knowledge relations), techne (its practice and geographies), identities (its souls and its bodies) and, in conclusion, its possible relations to the present.

This reading contributes to ongoing efforts to appreciate the geographies of Foucault's thought, and to consider how Foucault might help us think about geographies of power and resistance in ever more complex and useful ways. In his last two lecture courses Foucault reinforced his commitment to thinking about spatiality and placement, in both a more philosophical-methodological and a more empirical sense.

First, Foucault reiterated his philosophical-methodological commitment to the materiality of discourse, analysing it through located and performing bodies. Foucault re-inserts thinking, speaking, threatening and moving bodies back into the history of philosophy. At the furthest extreme is the Cynic body: voluntarily homeless, naked, urinating in the street, and masturbating in the square. This was not in spite of, but to put into practice, their philosophy. Foucault's ongoing project places 'abnormal' bodies centre stage, analysing them with the rigour we would a state, corporation, policy or apparatus. The geographically and socially marginal figure becomes, again, Foucault's perspective:

"Cynicism would be the broken mirror, as it were, for ancient philosophy. It is the broken mirror in which every philosopher can and must recognize himself, in which he [sic] can and must recognize the very image of philosophy, the reflection of what it is and should be, and of what he is and would like to be. And at the same time, the philosopher sees in this mirror something like a grimace, a violent, ugly, unsightly deformation in which there is no way in which he could recognize either himself or philosophy." (CT, 232)

. The geographies of the latter are twofold. First, parrhesia's risk emerged from its exact space of intervention (whether an Assembly, a royal court, a civic space [the agora], a temple, or the street). Second, parrhesia sought to change the world it intervened in to, taking aim at the city, the state and, even, the universe as the target of a courageous governmentality. In his last years, after a turn to sexuality and ethics which saw Foucault abandon the explicitly spatial work of his mid-career 'power' research (Howell, 2007), we find a thinker not just re-discovering the body as a site of truth and change, but re-discovering the spatial as a dimension through which power, subjectivity and, possibly, resistance came into being.

\section{Foucault's Resistance}

\section{Geographer's resistance}


Foucault's influence on the discipline of geography has been profound (Crampton and Elden, 2007) although he has largely been read as a theorist of "power" and not of "resistance", even when he is simultaneously read as insisting the two cannot be separated (Sharp, et al., 2000). While Foucault is used to open our eyes to new terrains in which power operated, and to show how this power was resisted, this often involved inverting the analysis of power rather than thinking about resistance in its own terms. That is, geographers have more often acted as parrhesiasts, identifying and challenging the working of power through the position of critique, rather than studying acts of resistance, and of parrhesiasts, themselves.

Numerous studies have, however, resulted in productive engagements with the functioning and challenging of disciplinary and governmental spaces. These have included studies of power, friendship and resistance in early twentieth-century British housing reform (Robinson, 2000), of moving, evading and refusing bodies in the gay bars of mid-20 ${ }^{\text {th }}$ century Seattle (Brown and Knopp, 2016), of how labouring bodies in colonial Ceylonese coffee plantations evaded and resisted the panoptic gaze of the planter (Duncan, 2002), of the protesting, refusing and litigating prostitutes of interwar colonial India (Legg, 2014) and of ideological and street-based protests against the census in 1980s West Germany (Hannah, 2011b).

While Foucault's work on neo-liberal governmentalities has been extensively used by economic geographers, Langley (2007) is one of the few to think about subjects as agents in (if not resistant to) investment, through a reading of Foucault's (1986b) The Care of the Self. Vasudevan's (2015) study of contemporary occupations of urban space as protesting claims of rights to the city tellingly concludes with Foucault's (CT, 340) analysis (of the Cynics) as creating other worlds via other lives. Within these examples we often find Foucauldian approaches used to explore resistance (bodies and power, subjugated knowledges, minor spaces, surveillance and citizenship) but rarely do we find Foucault's work on resistance used itself (although see Hannah 2011a on welfare biopolitics and resisting modern governmentalities). Barnett (2015) has used Foucault's 1980s work to help us rethink him as a (possible) theorist of resistance via problematizations. The frame here is explicitly not that of 'subjection/resistance' but of always-changing selves who might transform themselves differently in particular, concrete circumstances. Rosol (2014) comes close to mobilising Foucault as a theorist of resistance in her work on counter-conducts of expert knowledge and the resulting struggles against zoning policies in contemporary Vancouver. In so doing she draws upon Cadman's (2010) innovative paper which argued that geographers neglected the core role of counter-conducts, critique and the political in Foucault's governmentality work, themes which have been more widely addressed outside of geography. 


\section{Resisting resistance}

There is certainly no consensus within the broader literature on the subject of Foucault and resistance. At best the consensus is that Foucault studied acts of resistance but resisted the analytical category of resistance itself. Žižek (2000), for instance, suggests that Foucault has two incompatible models of resistance (as pre-existing power or as being generated by it) which his work on self-formation in antiquity attempted to unite. Armstrong (2008) counter-argues that Foucault is actually creating an approach to freedom which equates it neither with liberation from power nor with pure rebellion; rather, it emerges in response to events and forces external to the subject; from, perhaps, one's geographies. That is, if the historical ontology of power pushes us to name its historical-geographical specificities, then we must do so with resistance. Foucault was, however, willing to name contingent universals (see Koopman 2013) like governmentality and subjectivity, but less so with resistance.

Cornell and Seely $(2016,53)$ contrast the embrace by queer theory of Foucault, for his radical assaults on preconceived connections between power, sexuality and resistance, with Marxist theorists of revolution who view him as a "major enemy" who sees no way "outside" of power. In another comparative reading, Smith (2016) recounts the contrast between Deleuze's ontology, which was based on lines of flight and deterritorialisation, and Foucault's, which tended to posit apparatuses first and resistance second. Dissatisfaction with his settling of the question of resistance and governmentality led to Foucault's turn to ethics, with Smith posing the latter in the useful frame of reactive and active types of resistance (also see Checchi, 2014). While the former react against forms of power conceived of as external and are neutralised relatively simply, the latter are directed against oneself. This raises questions of what the subject could know (of episteme), of what they could be (identity) and of what they could do (techne). Being differently is here the active form of resistance; to be other.

The challenge, however, is to consider how this personal ethics might be linked to political change. For Hardt (2010) accusations that Foucault's capillary conception of power lacked an 'outside' from which to locate and direct resistance were a problem for orthodox Marxists and party-based politics, but not for Foucault himself, who continued to write about resistance and to campaign politically as a public intellectual (see Elden, 2016). Parrhesia emerged as the ethical and political mode of thought that would enable ways of thinking about struggle and politics. This may also have been a response to Foucault's visits to Iran and his coverage of the Iranian revolution against both the Shah's repressive regime and against western modernisation in favour of a "political spirituality" (cited in Raffnsøe, et al., 2016, 440). 
For Cornell and Seely this work is indispensable for rethinking the notion of revolution, reintroducing an emphasis on self-transformation. Reading across Foucault's writings on 1970s Iran and ancient parrhesia, the lesson they extract is that an overemphasis on the politics of liberation can distract attention from the ethical problem of freedom (Cornell and Seely, 2016, 77). Whilst domination must be resisted in the name of liberation, the gnarlier question of freedom demands ethical transformation which results, Foucault would insist, from the risky interaction of self and other. Foucault approached this question through, at least, three historical examples: the Cynics, critique, and counter-conduct.

In terms of the former, Shea $(2010,173)$ attributes Foucault's pursuit of the distinction between power relations and domination, and his commitment to studying the combatting of the latter, to his study of ancient ethical parrhesia, especially that of the Cynics. Shea clearly shows how Foucault linked the Cynic ethos to the emergence of critical philosophy in the Enlightenment (also see Raffnsøe, et al., 2016, chapter 11). Contrasting with his early-career condemnation of Enlightenment's tagging of truth to disciplinary policing of knowledge and bodies, Foucault embraced Kant's (1784) question 'What is Enlightenment' as the moment when philosophy began again to criticise its material and contemporary reality, and to begin to intervene in it.

At the level of individual de-subjugation, critique allows virtuous self-transformation which might expose the limit of the present, mining out ways of "not being governed" and questioning doctrinal truths, which owe their origins to the anti-pastoral (Reformation and counter-Reformation) movements of the $16^{\text {th }}$ century as much as to Kant (Butler, 2002). The source of resistance, in Butler's reading, is not internal to the subject but emerges in failing projects of governmentalization. Butler (2016) has recently insisted that we think of resistance emerging from material spaces that enable embodied mobility (whether of amassed protesters or of queer performativities). This commitment to exposing and using resistance is a hallmark both of Butler's Foucauldian sense of critique, but also of the exposed body most famously deployed in the ancient world by the Cynics.

A third historical practice drawn on by Foucault (1977-78 [2007]) was that of $16^{\text {th }}$ century Reformation practices of religious "counter-conduct", his refiguring of resistance in the governmentality lectures (Davidson, 2011). If governed subjects consent to be so conducted, the possibility of refusal must be everywhere (Cadman, 2010). But Foucault resisted the language of resistance, referring to these acts as revolts, disobedience, insubordination or dissidence (Lorenzini, 2016). Rather, counter-conducts pursued other means of being conducted, through asceticism (abstinence), alternative communities, mysticism, the return to Scripture, or eschatological ('end of times') beliefs (for contemporary applications see Death, 2016 and Roy, 2018). Foucault would return to many of these practices in his 
last lectures, not as acts of counter-conduct, but as the means by which early Christianity subsumed Cynic parrhesia.

This paper is an attempt to explore some of these links. Ethical parrhesiasts proffer the possibility of an ethical subject who, while not political, sought to alter the city and its people through their spatial practice and their embodied truth. Through the Cynics' grimace, Foucault aimed to fracture philosophy's noble reflection and present an alternative genealogy of the relationship of truth, government and self. The sections below will seek out a reflection of resistance through providing, if you will, a threefold coming together of shards:

\begin{tabular}{|l|l|l|l|}
\hline & Plato & Socrates & Cynics \\
\hline Episteme: the will to Truth & Philosophy into reality & Ironic interrogation & Changing truth \\
\hline Identity: the birth of two? & Facing the tyrant & The philosophical life & The insolent life \\
\hline $\begin{array}{l}\text { Techne: govern the city, } \\
\text { govern the human }\end{array}$ & Court & City & Street and universe \\
\hline
\end{tabular}

Table 1: three shards: analysing Foucault's 1980s

\section{Philosophical to Radical Parrhesia}

In his research leading up to and including the Self and Other lectures, Foucault had tracked the urge not just to 'know yourself' but also to 'care for yourself' in the ancient world. His discovery had been that, way before Christian modes of confession and spiritual guidance, this caring had become a practice for two. The Other could be a friend, lover, or tutor, but their core quality had to be that of parrhesia, which enabled the self to tell the truth about itself $(C T, 6)$. In the Self and Others lectures Foucault mostly focused on fifth century BCE Athens where he located the founding of parrhesia. To his surprise he found this founding parrhesia to be explicitly political. With the crisis of democracy in Athens (after the death of Pericles in 429 BCE) parrhesia shifted geography and target, from the Assembly and the citizens, to the royal Court and the Prince (the example of Plato in Syracuse, GSO, 303) or the street and the people (the example of Socrates and the Cynics in Courage of Truth). Here the philosophical parrhesiast rose into prominence and presents something closer to the resisting subject for Foucault. The reading below follows Foucault in reading Plato ahead of his elder tutor Socrates, whose philosophical parrhesia absented itself more completely from the political through deserting the Assembly or the Court for the city. The question to which we will return in the conclusion 
is: do these forms of parrhesia bring us closer to an analytics of resistance in the work of the latter, the last, Foucault?

\section{Episteme: the Will to Truth}

Plato: philosophy into reality

What forms of knowledge can parrhesia draw upon when it leaves the constitutional form of democracy in the post-Periclean age, when public parrhesia and democracy in Athens was undermined? Foucault examined the parrhesia of Plato as philosophy in an intimate embrace with political sovereignty. What, then, makes this parrhesia, and not the truth form of the sage or teacher? It is parrhesia because this form of knowledge finds its truth in confronting power. Why, then, is this philosophical not political parrhesia? Because it alights upon a new target, the practices of the governor's soul.

Plato (428/7-348/7 BCE) was Socrates' most famous student, recounting the latter's teachings and formulating an ordered system of fundamental philosophy (metaphysics) and of political philosophy. However, Foucault chooses to focus on Plato as an itinerant and engaged philosopher, beginning with Plutarch's account of him in the court of "the tyrant of Syracuse" (GSO, 48), Dionysius II, who ruled the Sicilian Greek colony from 367-356BCE. Dion, the brother of Dionysius's wife, was a student of Plato and beseeched his ex-master to come to Syracuse and educate the tyrant ruler. The initial meeting was a disaster. Plato lectured Dionysius on the nature of virtue, courage and justice, and was promptly ejected from court (Dionysius actually asked that while departing Syracuse Plato be killed or, at least, sold into slavery). Dion denounced Dionysius's behaviour, in an act described by Plutarch as parrhesia $(G S O, 50)$. But for Foucault, Plato's courageous truth-telling also marks a philosophical courage within a political frame. Dionysius later repented and Plato was recalled, although the visit, again, goes badly. Plato later reflected on this experience in his seventh letter, which for Foucault marks an attempt by a philosophical advisor to rationalise political action (GSO, 215).

What forms of knowledge are at play here? Why does Plato keep returning to Syracuse? Foucault suggests that it is because he was a parrhesiast. Like Socrates and the Cynics, he wanted to change the world, not just change forms of thought. Unlike his mentor, Socrates, he did not feel he could operate his parrhesia within Athenian democracy, so he opted to influence society by directing a ruler. Whilst Plato desired a better-ordered world via affecting Dionysius' policies, his motivation was also philosophical. Had he refused Dion's request “... then he would feel that he, Plato, was only logos, pure and simple discourse, whereas it is necessary for him, he wants to try his hand at, to put his hand to the ergon (that is to say, to the task, the work)" (GSO, 225). For Plato this is where philosophy's 
"reality" was to be found: "How [Foucault asked], in what way, on what form is philosophical truthtelling, the particular form of veridiction that is philosophy, inserted into reality?" $(G S O, 228)$ The answer, for Plato, was that philosophy finds its reality when it addresses itself to whoever exercises power. Other ethical parrhesiasts would find their truths elsewhere.

\section{Socrates: ironic interrogation}

Socrates (c470-399 BCE) sits within the founding canon of western philosophy but is mostly known through the accounts of others' (especially Plato) of his philosophical inquiries and interrogations. He was born around nine years after Pericles' rule began, growing up during his 32-year reign (the 'golden age' of Athenian democracy), and surviving him by 30 years before he was forced to take his own life for supposedly refusing the truth claims of the Assembly and for his corrupting influence on Athenian youths, and some of its politicians. For Foucault, Socrates' whole life is the playing out of a cycle between truth-telling and mortal risk, from his refusal to engage in Assembly politics because of the (bad) risk to his life, to his final acceptance of death for his beliefs $(C T, 74)$.

How does Socrates relate to truth forms? In one sense we have a familiar frame, from Foucault's previous readings of Oedipus and his reading of political parrhesia in Euripides' Ion in Self and Others; that of Apollo and the oracle at Delphi. On being asked which Greek was wiser than Socrates, the oracle had replied that there was none $(C T, 81)$. Socrates' whole life, the foundation of his braiding of truth and knowledge, was spent testing this oracular truth-claim through Socratic irony, through insisting he knew nothing as the basis for questioning what others knew. Subjecting Apollo to an interrogation, Socrates would spend his life testing himself and others, testing their knowledge, testing their patience, testing their ability to admit their own ignorance. This was his courage, the basis of his parrhesia, both irreducible to and inseparable from other forms of knowledge $(C T, 87)$ : from that of the sage (he knew the world but did not have geographical knowledge as his aim); from that of prophesy (he accepted but challenged Apollo); and from the knowledge of the teacher (he did not teach others what to know but what to do so as to learn). Related to these forms of knowledge but different, Socrates' ethical parrhesia took place through the testing of souls. His episteme is to be found through his practice, through verification, testing, investigation, and examination (CT, 122); through both the identities and techne of his work.

\section{Cynics: changing truth}

Socrates chose democracy over autocracy, the people over the prince, but his philosophical parrhesia is still recognisably comparable to that of his student, Plato. The Cynic to whom Foucault turns most regularly, Diogenes (412/404-323 BCE), admired Socrates but loathed the abstractions of Plato, his 
contemporary. He would disrupt his lectures, eating and drinking throughout and refusing his lessons. Plato branded him a 'Socrates gone mad'. Diogenes was just one of the Cynics who lived as scandal, breaking the conventions of the polis through urinating, copulating, defecating in public, living in the street and castigating the citizenry. This was a way of touching on and exposing its taken for granted truths.

Like Socrates, the Cynics are hard to analyse because of their dearth of written material. The added difficulty, unlike Socrates, is the diversity of Cynic figures to contend with, stretching from the fourth century BCE to the third century CE $(C T, 193)$. The Cynic was diverse (courtly and crude), ambiguous (natural and abhorrent), non-theoretical yet learned, and left their record not through teaching but through (anti-)hero figures (CT, 210). Despite this, Foucault insists that the Cynics had a scandalous epistemic effect on the field of philosophy itself. The scandal was their life and their questioning, but also their approach to truth. Their practice issued a radical challenge to the tenets of philosophy: "What is the true life?" (CT, 218) To understand the originality of the Cynic answer, Foucault sketched out some generally accepted Greek philosophical approaches to what truth was, recurring amongst all the philosophers recounted so far, as illustrated through true speech, love and life (CT, 218-228):

\begin{tabular}{|l|l|l|l|l|}
\hline To be true & True speech & True love & True life & Cynic Truth \\
\hline Not hidden & Nothing withheld & No subterfuge & Unashamed & Naked \\
\hline Pure & No false opinion & No displeasure & No evil, no vice & Destitute \\
\hline Straight & Obeys the law & Correct to custom & Conform to norms & Natural \\
\hline Unchanging & Cannot be refuted & Incorruptible & Shuns corruption & Incorruptible \\
\hline
\end{tabular}

Table 2: spoken, loving, living, and Cynic truth

The Cynics worked against these definitions operating, again, under the shadow of Apollo's light. After Diogenes and his father had been exiled from their homeland for counterfeiting, they visited Delphi and asked the oracle for advice. Apollo's reply was: "Change the value of the currency" (CT, 226). Foucault's interpretation is that the currency was that of truth itself, and that the epistemic project of the Cynics can only be understood through their embodiment of philosophical parrhesia as the way of discovering a new, true life (as in the fourth column above, explained below). As the philosophical tradition bolstered itself with the scientific logos of metaphysics, the philosopher's body became an "increasingly pointless" shadow $(C T, 236)$. Foucault aimed to restore that shadow to life.

\section{Identities: the Birth of Two?}

"Who is capable of being the artisan of parrēsia?" (GSO, 196) 
Human subjects had always been at the centre of Foucault's research. The insane, the patient, the convict, the sexual being, the lover of boys, the dreamer, the convert, the confessor, and the citizen had all been his subjects; identities as the target of governmentalities. In his final studies of parrhesia, however, Foucault's gaze upon the subject shifts. No longer are we looking at the effects of power on a subject, of the conduct of conduct (governmentality) or the action of self on self (ethics). We are now looking at the interaction of self and other, with the emphasis lying on the other, the director of souls. Veridiction, government and self-constitution come together here but the subject of ethical formation is not the only subject present in this triangulation. Rather, knowledge here is also expressed by a truth-teller. Two corners of this triangle, self and other, enter into a relationship, united in the psychogogic (crafting the soul) project of the third corner, that of government.

\section{Plato: facing the tyrant}

In facing down a tyrant Plato was named as a parrhesiast. In this he was guided by his views of the masses, such as that expressed in his Republic (c. 380 BCE) that the body of citizens are like an animal, the angers and appetites of which had to be learned (GSO, 211-212). But there is also a different subject-relation apparent in Plato; the work of the philosophical advisor (other on self) on themselves (self on self); that is, the practice of philosophy through "exercises" (GSO, 242). Plato asserts that one can only acquire philosophy through living with it, through the relationship of self to self. The aim is to have a philosopher and a politician working together, the governor having a connection to philosophy, the governor being able to govern his soul truly so as to govern others justly (GSO, 295). This psychogogic relation emerges through having the self and other live their philosophy, a practice touched upon but not taken up through his lived body by Plato, unlike his mentor, Socrates.

\section{Socrates: the philosophical life}

"It is this domain of existence, of the mode of existence, of the tropos [manner] of life, on which Socrates' discourse and parrhēsia will focus. So it is neither the chain of rationality, as in technical teaching, nor the soul's ontological mode of being, but the style of life, the way of living, the very form that one gives to life." (CT, 144)

Socrates, like Plato, stood back from politics, though his position was that of absolute refusal, not of philosophy within politics. Like Plato, Socrates tested himself through ergon not logos, but he did this not just through who he chose to address in his practice, but also in his way of being. We come here to parrhesia as a way of life, of the philosopher as an agent of truth, through their dress, their behaviour, their body (GSO, 32).

Rather than psychogogy, Socrates' mission was that of caring for life, through the body. From here one philosophical tradition led to metaphysics and an ontology of the self (Plato), another led to forms 
of life and the art of oneself (Socrates, CT, 127). The route to identity in parrhesia could come through discourse. Nicias explained to fellow Athenian statesman Laches, before he embarked on a dialogue with Socrates over the nature of courage, that the philosopher would force him to given an account of himself, the kind of life he had led in the past and led currently, which Socrates would then examine and test, in a parrhesiastic pact of courage between self and other (CT, 143). How do you live? McGushin $(2007,63)$ shows that this is not the demand for a confession, but a confrontation aimed at encouraging both resistance and care. Socratic parrhesia, for Foucault, constituted existence as an aesthetic object, a beautiful work, which demanded care so as to form one realisation of the true life (CT, 162).

Why did people accept this questioning by Socrates? Because of the second route to identity in parrhesia, that of the parrhesiast's body. Laches accepted Socrates' questions on courage not because he was courageous, but because of his 'symphony', a harmony between what he said and the unpretentious and unadorned way in which he lived. Both the target and the means of ethical parrhesia is life itself. Whilst for Socrates parrhesia was a challenge to those with whom he entered into dialogue, parrhesia also aimed to increase their care for themselves. The courage of Socrates was to make people care $(C T, 158)$. The Cynics were inspired by Socrates' binding of modes of life to truth telling, but they felt bound to push the connection to the level of "intolerable insolence" (CT 165).

Cynics: the insolent life

"With the Cynics, a naked, begging, and bestial life, or a life of shamelessness, destitution, and animality looms up on the borders of ancient philosophy..." (CT, 270)

For Foucault both Cynic and Socratic parrhesia arose from their immediate linking of mode of life and truth-telling $(C T, 237)$. Both believed philosophy should prepare one for life, that it should make one care for their life, that one should study life in its reality, and that one should live according to one's philosophy. But, in addition, the Cynics added the principle of 'changing the currency'. This involved challenging what constituted the true life in the sense of embodiment, and in terms of mode of existence.

In terms of embodiment, the Greco-Roman Cynic was the scout of humankind, moving ahead of it and assessing its dangers. This temporal, future-function required a spatial and contemporary roving. The Cynic would be without a shelter, a home or even a country (CT, 167). After mobilising his body, the Cynic then spoke of what he had seen, without fear. The Cynic body, though wild, was also codified, signified by the cloak, staff, bare feet and pouch of the beggar, unkempt and homeless (CT, 170). These elements enabled the Cynic in their search, they reduced their pointless obligations, and they exposed 
life in all its bare, true nakedness. The body of truth here becomes visible, laughable, through bare life; the corporeal, scandalous truth of the Cynic.

This mode of life was courageous because of its exposure of the Cynic body, in the sense of display and of risk (CT, 234). But the Cynics also challenged the very notion of a true life. Theirs was referred to as a dog's life (an epithet Diogenes took up with pride). They were without shame or modesty. They were destitute and indifferent. They were 'natural' lives, barking at enemies, distinguishing the good from bad with their senses. But they were also guard dogs, dedicated to saving others. Shameless, indifferent, discriminating and guarding, Foucault sees these characteristics as changing the currency of the true life (unconcealed, pure, straight and unchanging, see Table 2). This was not through reversing or challenging the true life, but through taking it to its scandalous conclusions. Take the unconcealed life to its extreme and you have the shameless, exposed body. The independent life, which needs nothing, becomes the indifferent life of voluntary poverty. The straight life becomes the barking discrimination between good and bad. The unchanging, incorruptible life becomes that of the guard dog (CT, 244).

Of the four components of the true life this latter part was associated by Foucault with sovereign life. That is, the unchanging life of self-possession, of being in a position to help others, of displaying to others the best of mankind (CT, 270-272). In scandalising the sovereignty of the true self the Cynics performed their most radical manoeuvre. While Plato had sought to govern the sovereign, the Cynics declared themselves sovereign and philosophically deposed their political kings. The most famous examples are the result of the, probably mythical, debate between Alexander the Great, ruler of Greece, and Diogenes, wretch who lived in the street. While Alexander's sovereignty required an army, that of Diogenes required nakedness. While Alexander had inherited his sovereignty, Diogenes had made his himself. While Alexander vanquished political enemies, Diogenes had vanquished his own faults and vices. While the King could lose his kingdom, Diogenes would be king, in nature, forever: "The Cynic is the only true king. And at the same time, vis-à-vis kings of the world, crowned kings sitting on their thrones, he is the anti-king who shows how hollow, illusory, and precarious the monarchy of kings is." (CT, 275) A life of battle, of struggle with the self and for others, theirs is the "militant life" (CT, 283).

\section{Techne: Govern the City, Govern the Human}

"What mode of knowledge, or what tekhne, what theory of practice, what body of knowledge, but also what exercise, what mathēsis and askēsis will make it possible to take up this parrēsia?" (GSO, 196) 
If the epistemic form of parrhesia directs us towards the specific and the contingent, how was truth operationalised in philosophical parrhesia? It operated through exposing the speaker to risk (GSO, 56), creating with the listener a "dramatics of discourse" $(\mathrm{GSO}, 68)$ in a particular scene. This is its geography: "... the irruption of the true discourse determines an open situation, or rather opens the situation and makes possible effects which are, precisely, not known." (GSO, 62)

Plato: court

The scene of Plato's parrhesia is given as much emphasis in Foucault's account as the dramatics of his courageous speaking. Whereas previously the scene was that of the democratic city and of citizens, now it is of the autocratic court and the philosopher, of the prince and his advisor. Plato finds abundant evidence of bad parrhesia in Athenian democracy, of un-directed free speech, of uncontrolled desires, of an absence of true discourses (GSO, 199-200). In the non-democratic Persian Empire of Cyrus, in contrast, he sees a leader distinguishing those worthy of friendship and of speech (GSO, 202, on the reflections on colonialism and governmentality in these lectures see Legg, 2018). In the context of declining Greek city-states and democracies and the formation of Hellenistic monarchies, "Although municipal democracy may still function, the main political problems will be shifted from the agora, which is, so to speak, municipalized, to the sovereign's court. The scene is now the sovereign, the court, the sovereign's entourage." (GSO, 210) But, vitally, Plato's object was still the good governance of the city, although he felt the realities of his context meant that the best way to affect the city was through advising the tyrant, not through imagining ideal republics. As Foucault proposed, "... I think that if the logos is in fact related to the construction of the ideal city, then the ergon, which must complete the philosopher's task with regard to politics, is actually the task of the political counselor and of the elaboration, through the Prince's soul, of the rationality of the real conduct of the city." (GSO, 219).

How, then, would Plato would enact the dramatics of his parrhesia; what would his advice be to the various Syracusans who asked for his views? Foucault warns the reader that, on the face of it, Plato's advice is a banal and uninteresting disappointment (GSO, 260). What we get are general treatises on philosophy not politics, on the moral not the political, on prioritising justice, reconciliation and friendship. This is Plato as diagnostician, analysing the failure to create trust within the Sicilian Empire, and encouraging comparisons with Persian and Athenian imperial governmentalities. While advice upon structuring the networks of empire was given, Plato's techne is routed through the Prince, his geography confined to the court unless the ruler acts upon his advice.

Socrates: city 
The body and identity of ethical parrhesiasts was, to a great extent, their techne. But there is an ambiguity in Foucault's reading regarding the utility of these works, especially regarding the city. We are told that the emphasis has moved from the city and the citizen to the individual and their conduct (CT, 34). But we are also told that parrhesia "... has, of course, something to do with technique, but it is also a role which is useful, valuable, and indispensable for the city and for individuals." (CT, 14) Socrates presents himself, in contrast to those trained in the arts of rhetoric and addressing the city, as the man of truth-telling without any tekhne (GSO, 312, 336). Yet his mode of parrhesia was to tour the city, freely giving advice, acting as the irritating gadfly that would rouse the Athenian population from their slumber.

While he felt the risk of parrhesia in the Assembly would not have been useful, due to the state of politics at the time, he felt his touring of the city could help the people. This is why, in Plato's Apology, Socrates insists that he can be most useful to the city by not serving it politically. As Foucault ventriloquised Socrates: "By encouraging you to take care of yourselves I am useful to the whole city. And if I protect my life, it is precisely in the city's interest. It is in the city's interest to protect the true discourse, the courageous veridiction which encourages citizens to take care of themselves." $(C T, 90)$ Socrates aimed to cure the city of its ills, not as Plato did through advising the governor, but through working for the moral health of the citizens $(C T, 110)$. The techne that Socrates appeals to is that of the technician of care, of the therapist of the soul $(C T, 134)$. This techne intervenes not in the polis, we could say, of politics, but into the city of bodies and souls (GSO, 327).

\section{Cynics: street and universe}

Foucault presented us with two geographies of the Cynics, the first spanning his last two lecture courses, the second coming as the culmination of his final course. The former geographies concerned the city, the latter concerned the universe and the prospect of an Other life.

The materiel for the Cynic's scandalous assaults was the city. It provided them with the weapons and infrastructure for their militant life: "an overt, universal, aggressive militancy; militancy in the world and against the world." (CT 285). While the Cynics rejected the politically sovereign life, they also rejected the conventions and laws of the city (the polis, GSO 287). They rejected the most basic divisions of urban space (public/private) by living in the street and conducting their dangerous work there ("The Cynics are men of the street, of the agora" GSO, 291, also see CT 253). While Plato had withdrawn to the Court, the Cynics remained men of the city. This question of the techne of this truthtelling, of the application of ethical parrhesia was central: "What is the site of truth-telling? Where can truth-telling find its place, on what conditions can and must room be made for it?" (GSO, 305). 
This question was taken up again in the Courage of Truth lectures, drawing on accounts of the Cynics posted on street corners, in lanes and at the doors of the temple, practicing a "popular philosophy" (CT 203-4). But the emphasis in these final lectures moved from the micro to the macro geographies of Cynic parrhesia. This move was from the sites of truth-telling to its object. At what did the Cynics aim with their assaults? What did they hope to affect, through their bodies and those of their targets? For Foucault, Cynics used their embodiment of the true life to insert a radical otherness into the city. This would not raise Plato's question of an other world, an ideal or metaphysical realm that was elsewhere. It posed the other life in the here and now, as an immediate way of changing a place through caring for the self differently (CT, 245-6). The exposed, destitute, barking, sovereign life of the true-king Cynic was, therefore, exposed as a life of dedication to relentless public work of self on self, of caring through diatribe and attack (CT 278-9). What was under attack was not just individual vice but the vice of humankind in its real life, which could only be changed by altering its customs, conventions and ways of living (CT 280, 294). Free of commitments the Cynic "... appears as a sort of universal night-watchman who keeps watch over the sleep of humankind... The Cynic is a functionary of humanity in general; he is a functionary of ethical universality." (CT 301) By freeing himself of domestic ties to the geographies of the city, the Cynic could attend to universality of all humans, to “... the government of the universe." (CT 303)

\section{Conclusions: Parrhesia as Resistance in the last Foucault?}

\section{The vertigo of a familiar past}

Despite the antiquity of his materials, Foucault returned to presentist pointers throughout the parrhesia lectures ("... to try to justify constantly enclosing you within ancient philosophy" CT, 174). He recapped this work as "obviously a sort of prehistory" of practices which later emerged around other famous sets of couples, namely: the penitent and the confessor; the guided subject and the spiritual director; the sick person and the psychiatrist; the patient and the psychoanalyst (CT, 7 also see Foucault and Burchell 2015, 220). The last lecture course opened not with the ancient world but with material on Kant and critique, and Foucault suggested repeatedly that the Enlightenment saw the re-emergence of parrhesia after centuries of dormancy. The site, and cause, of this hibernation was the Christian Church and, especially, its yoking of the disruptive potential of parrhesia to the command "tell me who you are".

Foucault's argument here positions the Courage of Truth lectures as leading, chronologically, to his arguments made in the Government of the Living (Foucault, 1979-80 [2014]) course, four years 
previously, which described the truth regime of early Christianity (see Foucault 1981 [2014] and Legg, 2016). Foucault now suggested that around the second century CE Christian teaching took over the parrhesiastic function from the Cynic tradition and divested it of its philosophy (GSO, 348-50). A new relationship of the true life via Christian asceticism resulted that would renounce the world in devotion to an other world; that of heaven. This would in general mark a geographic turn inward to the monastery away from the risks and lives of the city. Foucault suggested that he planned to lecture on the turn from pagan to Christian asceticism in the following year's lectures, and hinted at what they might have covered; he died three months later. They would have touched on shared practices of ascesis (modes of endurance and exercise) in terms of food, fasting and diet (in which Christians were more radical than (ynics), in terms of scandalous indifference to others, and in terms of an animalistic naturalness of life (CT, 317-8). What was new in the Christian asceticism was the emphasis on the other world, of heaven, as the target of the other life and a new emphasis on obedience to god, to the law, and to one's master: "There is true life only through obedience to the other, and there is true life only for access to the other world." (CT, 320). The Platonic metaphysical other world and the JudeoChristian emphasis on the pastorate inflected Cynic asceticism within this new Christian truth regime. Parrhesia transitioned here from talking to others to talking to God, proving obedience to him (CT, 330). It would continue as a courageous boldness, but mainly in defending God's faith against doubters. Individual scandalous boldness, Foucault suggested, became clouded over by the governmentalities of the Christian church:

"And this theme of parrhèsia-confidence will be replaced by the principle of a trembling obedience, in which the Christian will have to fear God and recognise the necessity of submitting to His will, and to the will of those who represent Him. We will see the development of the theme of mistrust of oneself, as well as the rule of silence." (CT, 333)

Bold, brave closeness to God now came to seem like arrogance and presumption; truth would come from a director, via institutions like monasteries, churches and the pastorate more broadly. These, for Foucault, are the mechanisms of claiming and shaming philosophical parrhesia:

"Parrhēsia appears incompatible with the severe gaze that one must now focus on oneself. The person who can bring about his salvation - that is to say, who fears God, who feels himself to be a stranger in the world, who keeps a watch on himself, and must constantly keep a watch on himself-cannot have that parrhesia, that jubilant confidence by which he was bound to God, borne up to grasp Him in a direct faceto-face encounter. So parrhesia now appears as a blameworthy behavior of presumption, familiarity, and arrogant self-confidence." (CT, 334)

\section{After fearless speech}


This was the message Foucault delivered in his last lecture. What we are presented with is the subjugation of militant, scandalous Cynic parrhesia, submitting to the demand "tell me who you are." Foucault is regularly criticised for his refusal to condemn the ethos of the governmentalities he described, whether of Taylorisation, famine policies, or neo-liberalism. But the language here, of trembling obedience, submitting to His will, and blame-worthy self-confidence, suggests a genuine regret at the cowing of the Cynic.

Yet, unlike in his previous courses, Foucault repeatedly suggests that this subjugated tradition survived in diverse practices, including the Christian counter-conducts mentioned above (CT, 182, 337). Perhaps Foucault's most unexpected suggestion was that this trans-historical Cynicism could also be found in modern politics (for a retrospective reading of Foucault's earler works in the light of his last, see McGushin, 2007). Here Foucault was thinking foremost of nineteenth-century revolutionary movements which, he suggests, took from Cynicism the idea of a mode of life as "... the irruptive, violent, scandalous manifestation of the truth ..." (CT, 183). Revolution here was organised through secret societies, social organisations, and as a style of existence which embodied the other life, which is true life, to the point of being willing to die for the truth.

Shared across these suggested survivals of the Cynic mission were the commitment to a militantism which, crucially, demanded personal renunciation and destitution so as to battle to change the whole world (CT, 286). That is, each of these seemingly individualistic forms of resistance seeks to change the world. Though viewed as personal relations (ethics), they have a relationship to a truth-knowledge claims (veridiction) and the conduct of others (power). That is, they can be viewed themselves as governmentalities that seek to make better geographies, which "... transpose[s] anew the idea of an other life into the theme of a life whose otherness must lead to the change of the world. An other life for an other world." (CT, 287, emphasis in original). Central not marginal, these militant subjects merited Foucault's full attention as vital governmentalities because (not in spite) of resembling what we might call 'resistance'.

Casting back, therefore, how can these works of the last Foucault on parrhesia help us with the hackneyed but vital question of resistance and the ongoing challenge of analysing governmentalities spatially? In terms of the former, Foucault clearly continued to resist the term, or offer an historical ontology of what resistance is or was, but he did brand Cynic parrhesia as scandalous, intolerable, militant and radical. While Plato and Socrates seem less obviously resistant, Foucault insisted that they were also parrhesiasts, though through what we might call elite 'policy advice' and individual therapy rather than systemic challenge. Reading across his three parrhesistic foci, the first lesson is that approaching parrhesia as a form of power (whether political or as a more dispersed ethic of care) does 
not mean that it was neutralised or compromised; as contestation it could still have the power to mobilise, to inspire, to discipline a movement, or to plan an alternative future. In this sense we can view acts we might label resistant as alternative acts of power (within broader counter-conducts or critiques) that should be studied using the full analytical range of governmentality studies, much as we would a state, corporation, policy or apparatus. The second lesson is that when seemingly resistant acts become problematized and neutralised (such as via Cynic subsumption into Christian truth practices) these subjugated practices can survive and re-emerge in new and vitalised ways and forms (via the Reformation, the Enlightenment, or revolutionary militant lives).

In terms of geographical analysis, the reading above has highlighted the value of the last Foucault lectures in both a philosophical-methodological and an empirical sense. The lectures affirm Foucault's commitment to tracing governmentalities genealogically, through bodies in particular spaces, acting on freedoms and constraints that emerge through the dramatics of discourse, as mobilised by thinking, moving, speaking, and corporeal bodies. From Plato's exercises of philosophical interaction with his subjects, to Socrates's roving, ironic interrogations of Athenians' ways of life, to the vulgar challenges to privilege and entitlement barked out by the Cynics, the forms of truth, knowledge and power here are inseparable from their materiality, their embodiment, and the reality of their location. Foucault provides us with rich empiricaly detailing of these geographies. These range from medium scale analyses, such as from the democratic city to the authoritarian court, or the debates about how best to order Mediterranean empires so as to govern well and truthfully.

But it is the geographies of the city that are most often invoked here, of Socrates haunting bakeries and docks, testing himself and others in the everyday spaces of Athens, or of the Cynics living without shelter in the street and the square. In the later, Christian period, parrhesiastic practices would, Foucault suggested, leave the people of the city and withdraw to the hermetic spaces of the monastery and the cloister. This movement would disrupt the geographical connection between the micro and the macro, which the Cynics had attempted to enact in the public spaces of the city. While they had attempted to make another world in the city, Christian thought would discipline the body on the promise of an other-world in an after-life.

Foucault's last lectures provoke us to rethink the influence of governmentality studies within geography and to apply and test it in new ways. They reinforce long-standing campaigns within and beyond geography, which insist that we study knowledge and truth claims as embodied and materially manifested, with all the potential for insurgence and creative disruption this focus allows. They remind us that risky truth-telling can take place within seats of power, whether as policy advice, expert testimony or judicial witnessing, as well as in radical spaces of alterity. The post-Enlightenment 
genealogy of parrhesia Foucault sketched out suggests that we might profitably consider the parrhesiatic geographies of militant activists, whether in a squat, camp, or coordinating hub, as ethical spaces, linking protesting bodies to virtual yet actualisable other worlds in the here and now.

What is clear is that spaces of resistant acts were vital to Foucault's understanding of the world, but that he resisted resistance as an analytical frame for linking governmentalities and political change because of its binary tagging to liberation or rebellion. While insisting we pursue public liberation from domination, his lesson was that freedom must also be sought within the individual, so as to complement systemic challenges to ingrained injustice. To study these resistant acts as power, as parrhesia, is to acknowledge their fragile vulnerability to internalisation and neutralisation and their potential as future and insolent governmentalities.

\section{References}

Armstrong, A. (2008) Beyond resistance: A response to Zizek's critique of Foucault's subject of freedom Parrhesia: A journal of critical philosophy 2008, 19-31.

Barnett, C. (2015). On Problematization: Elaborations on a Theme in "Late Foucault". nonsite.org 16. Brown, M. and Knopp, L. (2016) Sex, drink, and state anxieties: governance through the gay bar Social \& Cultural Geography 17, 335-358.

Butler, J. (2002) What is Critique? An Essay on Foucault's Virtue. In The Political. (Ed, D. Ingram) Blackwell, Oxford, pp. 212-228

--- (2016) Rethinking vulnerability and resistance. In Vulnerability in resistance. (Eds, J. Butler, Z. Gambetti and L. Sabsay) Duke University Press, Durham, NC; London, pp. 12-27

Cadman, L. (2010) How (not) to be governed: Foucault, critique, and the political Environment and Planning D: Society and Space 28, 539-556.

Checchi, M. (2014) Spotting the Primacy of Resistance in the Virtual Encounter of Foucault and Deleuze Foucault Studies, 197-212.

Cornell, D. and Seely, S. D. (2016) The Spirit of Revolution: Beyond the Dead Ends of Man. Wiley: Cambridge

Crampton, J. and Elden, S. (Eds.) (2007) Space, Knowledge, and Power: Foucault and Geography, Ashgate, Aldershot.

Davidson, A. I. (2011) In praise of counter-conduct History of the Human Sciences 24, 25-41.

Death, C. (2016) Counter-Conducts as a Mode of Resistance: Ways of "Not Being Like That" in South Africa Global Society 30, 201-217. 
Duncan, J. S. (2002) Embodying colonialism? Domination and resistance in nineteenth- century Ceylonese coffee plantations Journal of Historical Geography 28, 317-338.

Elden, S. (2016) Foucault's Last Decade Polity Press: Cambridge

Folkers, A. (2016) Daring the truth: Foucault, parrhesia and the genealogy of critique Theory, Culture \& Society 33, 3-28.

Foucault, M. (1977-78 [2007]) Security, Territory, Population: Lectures at the Collège de France 197778. Palgrave Macmillan: Basingstoke; New York

--- (1979) The history of sexuality volume 1: the will to knowledge. Allen Lane: London

--- Foucault, M. and Sassine, F. (1979 [2016]) There can't be societies without uprisings. In Foucault and the Making of Subjects. (Eds, L. Cremonesi, O. Irrera, D. Lorenzini and M. Tazzioli) Rowman \& Littlefield, London, pp. 25-52

--- (1979-80 [2014]) On the Government of the Living: Lectures at the Collège de France 1979-1980. Palgrave Macmillan: Basingstoke

--- (1981 [2014]) Wrong-Doing, Truth-Telling: The Function of Avowal in Justice. University of Chicago Press: Chicago--- (1982-83 [2010]) The Government of Self and Others: Lectures at the Collège de France 1982-1983. Palgrave: Basingstoke

--- (1982 [2001]) The subject and power. In Essential Works of Foucault, 1954-1984: Power. Vol. 3 (Ed, J. D. Faubion) Penguin, London, pp. 326-349

--- (1983-84 [2011]) The Courage of Truth (the Government of Self and Others II): Lectures at the Collège de France 1983-1984. Palgrave: Basingstoke

--- (1986a) The history of sexuality volume 2: the use of pleasure. Viking: London

--- (1986b) The history of sexuality volume 3: care of the self. Allen Lane: London

Foucault, M. and Burchell, G. (2015) Parrēsia Critical Inquiry 41, 219-253.

Golder, B. and Fitzpatrick, P. (2008) Foucault's Law Routledge: London

Hannah, M. G. (2011a) Biopower, Life and Left Politics Antipode 43, 1034-1055.

Hannah, M. G. (2011b) Dark Territory in the Information Age: Learning from the West German Census Controversies of the 1980s. Ashgate: Aldershot

Hardt, M. (2010) Militant Life New Left Review 64, 151-160.

Howell, P. (2007) Foucault, Sexuality, Geography. In Space, Knowledge, and Power: Foucault and Geography. (Eds, J. Crampton and S. Elden) Ashgate, Aldershot, pp. 291-316

Joronen, M. (2017) "Refusing to be a victim, refusing to be an enemy". Form-of-life as resistance in the Palestinian struggle against settler colonialism Political Geography 56, 91-100.

Koopman, C. (2013) Genealogy as Critique: Foucault and the Problems of Modernity. Indiana University Press: Bloomington 
Langley, P. (2007) Uncertain Subjects of Anglo-American Financialization. Cultural Critique 65, 67-91.

Legg, S. (2014) Prostitution and the ends of empire: scale, governmentalities and interwar India. Duke University Press: Durham, NC

--- (2016) Subject to truth: Before and after governmentality in Foucault's 1970s Environment and Planning D: Society and Space 34, 858-876.

--- (2018) Colonial and Nationalist Truth Regimes: Empire, Europe and the Latter Foucault. In South Asian Governmentalities: Michel Foucault and the Question of Postcolonial Orderings (Eds, S. Legg and D. Heath) Cambridge University Press, New Delhi, pp. 106-133

Lorenzini, D. (2016) From counter-conduct to critical attitude: Michel Foucault and the art of not being governed quite so much Foucault Studies 21, 7-21.

McGushin, E. F. (2007) Foucault's Askesis: An Introduction to the Philosophical Life. Northwestern University Press: Evanston, III

Raffnsøe, S., Gudmand-Hoyer, M. and Thaning, M. S. (2016) Michel Foucault: A Research Companion. Palgrave Macmillan UK: London

Ransom, J. S. (1997) Foucault's Discipline: The Politics of Subjectivity. Duke University Press: Durham, N.C.; London

Robinson, J. (2000) Power as friendship: spatiality, femininity and 'noisy surveillance'. In Entanglements of power: geographies of domination \& resistance. (Eds, R. Paddison, C. Philo, P. Routledge and J. P. Sharp) Routledge, London, pp. 67-92

Rosol, M. (2014) On resistance in the post-political city: conduct and counter-conduct in Vancouver Space and Polity 18, 70-84.

Routledge, P. (2009) Resistance. In The Dictionary of Human Geography. (Eds, D. Gregory, R. Johnston, G. Pratt, M. Watts and S. Whatmore) Wiley-Blackwell, Oxford, pp. 646-647

Roy, S. (2018) Changing the Subject: from Feminist Governmentality to Technologies of the (Feminist) Self. In South Asian Governmentalities: Michel Foucault and the Question of Postcolonial Orderings (Eds, S. Legg and D. Heath) Cambridge University Press, New Delhi, pp. 200-223

Said, E., Beezer, A. and Osbourne, P. (1993 [2004]) Orientalism and after. In Power, politics and culture: interviews with Edward W. Said. (Ed, G. Viswanathan) Bloomsbury, London, pp. 208-232

Schlosser, K. (2008) Bio-Political Geographies Geography Compass 2, 1621-1634.

Sharp, J. P., Routledge, P., Philo, C. and Paddison, R. (Eds.) (2000) Entanglements of power: geographies of domination \& resistance, Routledge, London.

Shea, L. (2010) The Cynic Enlightenment: Diogenes in the Salon. Johns Hopkins University Press: Baltimore 
Smith, D. W. (2016) Two concepts of resistance: Foucault and Deleuze. In Between Deleuze and Foucault. (Eds, N. Morar, T. Nail and D. W. Smith) Edinburgh University Press, pp. 264-282

Vasudevan, A. (2015) The autonomous city:Towards a critical geography of occupation Progress in Human Geography 39, 316-337.

Žižek, S. (2000) The Ticklish Subject: The Absent Centre of Political Ontology. Verso: London 